\title{
Decay Mechanism of NO3 Radical in Highly Concentrated Nitrate and Nitric Acidic Solutions in the Absence and Presence of Hydrazine
}

DOI:

10.1021/acs.jpcb.6b02915

\section{Document Version}

Accepted author manuscript

Link to publication record in Manchester Research Explorer

Citation for published version (APA):

Garaixd, G., Horne, G., Venault, L., Moisy, P., Pimblott, S., Marignier, JL., \& Mostafavi, M. (2016). Decay Mechanism of NO3 Radical in Highly Concentrated Nitrate and Nitric Acidic Solutions in the Absence and Presence of Hydrazine. Journal of Physical Chemistry B, 120(22). https://doi.org/10.1021/acs.jpcb.6b02915

Published in:

Journal of Physical Chemistry B

\section{Citing this paper}

Please note that where the full-text provided on Manchester Research Explorer is the Author Accepted Manuscript or Proof version this may differ from the final Published version. If citing, it is advised that you check and use the publisher's definitive version.

\section{General rights}

Copyright and moral rights for the publications made accessible in the Research Explorer are retained by the authors and/or other copyright owners and it is a condition of accessing publications that users recognise and abide by the legal requirements associated with these rights.

\section{Takedown policy}

If you believe that this document breaches copyright please refer to the University of Manchester's Takedown Procedures [http://man.ac.uk/04Y6Bo] or contact uml.scholarlycommunications@manchester.ac.uk providing relevant details, so we can investigate your claim.

\section{OPEN ACCESS}




\title{
Decay Mechanism of $\mathrm{NO}_{3} \cdot$ Radical in Highly Concentrated Nitrate and Nitric Acidic Solutions in the Absence and Presence of Hydrazine
}

\author{
Guillaume Garaix ${ }^{\mathrm{d}}$, Gregory P. Horne ${ }^{\mathrm{a}, \mathrm{b}, \mathrm{c}}$, Laurent Venault ${ }^{\mathrm{d}}$, Philippe Moisy ${ }^{\mathrm{d}}$, \\ Simon M. Pimblott ${ }^{\text {b, }}$, Jean-Louis Marignier ${ }^{\mathrm{a}}$, and Mehran Mostafavi ${ }^{\mathrm{a}, *}$ \\ ${ }^{a}$ Laboratoire de Chimie Physique, CNRS/Université Paris-Sud, Bâtiment 349, 91405 Orsay, France \\ ${ }^{\mathrm{b}}$ The University of Manchester Dalton Cumbrian Facility, Westlakes Science and Technology Park, \\ Moor Row, Cumbria, CA24 3HA, United Kingdom. \\ ${ }^{\mathrm{c}}$ The University of Manchester, School of Chemistry, Oxford Road, Manchester M13 9PL, United \\ Kingdom. \\ ${ }^{d}$ French Alternative Energies and Atomic Energy Commission, CEA, Nuclear Energy Division, \\ Radiochemistry \& Processes Department, DRCP, BP 17171, F-30207 Bagnols sur Cèze, France
}

\begin{abstract}
The decay mechanism of $\mathrm{NO}_{3}{ }^{\circ}$ has been determined through a combination of experiment and calculation for $7 \mathrm{~mol} \mathrm{dm}{ }^{-3}$ solutions of deaerated aqueous $\mathrm{LiNO}_{3}$ and $\mathrm{HNO}_{3}$, in the absence and presence of hydrazine $\left(\mathrm{N}_{2} \mathrm{H}_{4}, \mathrm{~N}_{2} \mathrm{H}_{5}{ }^{+}\right.$and $\left.\mathrm{N}_{2} \mathrm{H}_{6}{ }^{2+}\right)$. In the absence of hydrazine, the predominant $\mathrm{NO}_{3}{ }^{\circ}$ decay pathways are strongly dependent upon the $\mathrm{pH}$ of the solution. For neat neutral $\mathrm{pH} \mathrm{LiNO}_{3}$ solutions $\left(7 \mathrm{~mol} \mathrm{dm}^{-3}\right), \mathrm{NO}_{3}{ }^{\cdot}$ produced by the pulse is fully consumed within $160 \mu$ s by $\mathrm{OH}^{*}(37 \%), \mathrm{H}_{2} \mathrm{O}(29 \%), \mathrm{NO}_{2}{ }^{-}(17 \%)$, and $\mathrm{NO}_{2}$ (17\%). For acidic $\mathrm{HNO}_{3}$ solutions $\left(7 \mathrm{~mol} \mathrm{dm}{ }^{-3}\right)$, radiolytically produced $\mathrm{NO}_{3}{ }^{\cdot}$ is predominantly consumed within $1 \mathrm{~ms}$ by $\mathrm{HNO}_{2}(15 \%)$ and $\mathrm{NO}_{2}$ (80\%). Intervening formulations exhibit the mechanistic transition from neat $\mathrm{LiNO}_{3}$ to neat $\mathrm{HNO}_{3}$. In highly acidic nitric acid solution, hydrazine exists mainly as $\mathrm{N}_{2} \mathrm{H}_{5}{ }^{+}$and $\mathrm{N}_{2} \mathrm{H}_{6}{ }^{2+}$ both of which rapidly consume $\mathrm{NO}_{3}{ }^{\bullet}$ in addition to other decay mechanisms, with rate constants of $2.9( \pm 0.9) \times 10^{7}$ and $1.3( \pm 0.3) \times 10^{6} \mathrm{dm}^{3}$ $\mathrm{mol}^{-1} \mathrm{~s}^{-1}$, respectively.
\end{abstract}




\section{INTRODUCTION}

Concentrated aqueous solutions of nitrate ion $\left(\mathrm{NO}_{3}{ }^{-}\right)$and undissociated nitric acid $\left(\mathrm{HNO}_{3}\right)$ are commonly used in the nuclear industry for the dissolution of radionuclides, e.g. in spent nuclear fuel reprocessing solvent systems and in the storage of highly radioactive liquid waste. ${ }^{1,2}$ In these environments, $\mathrm{NO}_{3}{ }^{-}$and $\mathrm{HNO}_{3}$ are subjected to intense multi-component radiation fields which induce radiolytic degradation. ${ }^{1,3}$ The direct and indirect effects of radiation lead to the formation of a number of radiolytic products, particularly nitrogen oxides (e.g. $\mathrm{NO}_{3}{ }^{\circ}, \mathrm{NO}_{2}{ }^{\circ}, \mathrm{N}_{2} \mathrm{O}_{4}, \mathrm{NO}_{2}{ }^{-}$, and $\mathrm{HNO}_{2}$.) which play a significant role in altering the physical and chemical properties of aqueous $\mathrm{NO}_{3}{ }^{-} / \mathrm{HNO}_{3}$ solutions and solvent systems. ${ }^{1,3}$ The proportions of these nitrogen oxides are dependent upon the respective concentrations of $\mathrm{NO}_{3}{ }^{-}$and $\mathrm{HNO}_{3}$, and the nature of the irradiation conditions (type of radiation and its associated energy). ${ }^{4}$ The radiolytic formation of these species can be described by the simplified reaction scheme given in Table 1.

Table 1. Reaction scheme and rate constants for the radiolytic formation of key nitrogen oxides $\left(\mathrm{NO}_{3}{ }^{-}, \mathrm{NO}_{2}{ }^{-}, \mathrm{N}_{2} \mathrm{O}_{4}, \mathrm{NO}_{2}{ }^{-}\right.$, and $\mathrm{HNO}_{2}$. $)$ from the radiolysis of aqueous $\mathrm{NO}_{3}{ }^{-}$and $\mathrm{HNO}_{3}$.

\begin{tabular}{l|l|l|l}
\hline Number & Chemical Reaction & $\begin{array}{l}\text { Rate Constant } \\
\left(\mathrm{dm}^{3} \mathrm{~mol}^{-1} \mathrm{~s}^{-1}\right)\end{array}$ & Reference \\
\hline $\mathbf{1}$ & $\mathrm{NO}_{3}{ }^{-} m \mathrm{NO}_{3}^{-} * \rightarrow \mathrm{NO}_{2}^{-}+\mathrm{O}$ & $\mathrm{N} / \mathrm{A}$ & 5 \\
\hline $\mathbf{2}$ & $\mathrm{NO}_{3}{ }^{-} m \mathrm{NO}_{3}^{-} * \rightarrow \mathrm{NO}_{3}{ }^{-}+\mathrm{e}^{-}$ & $\mathrm{N} / \mathrm{A}$ & 5 \\
\hline $\mathbf{3}$ & $\mathrm{HNO}_{3} m \mathrm{HNO}_{3}{ }^{*} \rightarrow \mathrm{HNO}_{2}+\mathrm{O}$ & $\mathrm{N} / \mathrm{A}$ & 5 \\
\hline $\mathbf{4}$ & $\mathrm{NO}_{3}{ }^{-}+\mathrm{e}_{\mathrm{pre}^{-} \rightarrow \mathrm{NO}_{3}{ }^{-2-}}$ & $1 \times 10^{13}$ & 6 \\
\hline $\mathbf{5}$ & $\mathrm{NO}_{3}{ }^{-}+\mathrm{e}_{\mathrm{aq}}{ }^{-} \rightarrow \mathrm{NO}_{3}{ }^{-2}$ & $9.7 \times 10^{9}$ & 7 \\
\hline $\mathbf{6}$ & $\mathrm{NO}_{3}{ }^{-}+\mathrm{H}^{\cdot} \rightarrow \mathrm{HNO}_{3}{ }^{-}$ & $1.0 \times 10^{7}$ & 8 \\
\hline $\mathbf{7}$ & $\mathrm{NO}_{3}{ }^{-2}+\mathrm{H}_{2} \mathrm{O} \rightarrow \mathrm{NO}_{2}{ }^{-}+2 \mathrm{OH}^{-}$ & $1.0 \times 10^{3}$ & 8,9 \\
\hline $\mathbf{8}$ & $\mathrm{HNO}_{3}{ }^{-} \rightarrow \mathrm{NO}_{2}{ }^{-}+\mathrm{OH}^{-}$ & $2.0 \times 10^{5}\left(\mathrm{~s}^{-1}\right)$ & 8,9 \\
\hline $\mathbf{9}$ & $\mathrm{NO}_{2}{ }^{-}+\mathrm{NO}_{2}{ }^{\cdot} \rightarrow \mathrm{N}_{2} \mathrm{O}_{4}$ & $4.5 \times 10^{8}$ & 10 \\
\hline $\mathbf{1 0}$ & $\mathrm{N}_{2} \mathrm{O}_{4}+\mathrm{H}_{2} \mathrm{O}_{\rightarrow} \rightarrow \mathrm{HNO}_{2}+\mathrm{HNO}_{3}$ & 18 & 10 \\
\hline $\mathbf{1 1}$ & $\mathrm{HNO}_{2} \rightarrow \mathrm{NO}_{2}{ }^{-}+\mathrm{H}_{\mathrm{aq}}{ }^{+}$ & $3 \times 10^{7}\left(\mathrm{~s}^{-1}\right)$ & 11 \\
\hline
\end{tabular}

The radiolytic formation and decay of the nitrate radical $\left(\mathrm{NO}_{3}{ }^{\circ}\right)$ is of practical importance to these nuclear applications, as it is a significant driver of chemical change, be it through the formation of secondary radiolytic products (e.g. electron transfer from inorganic species, hydrogen abstraction from saturated organic species, and radical addition to unsaturated 
organic species), or through the oxidation $\left(\mathrm{E}^{\circ}=2.45-2.67 \mathrm{~V}_{\mathrm{NHE}}\right)$ of important metal ions (e.g. uranium, plutonium and fission products). ${ }^{4}$ Consequently, numerous pulse radiolysis and photolysis experiments have been performed to determine the radiolytic formation and decay pathways of $\mathrm{NO}_{3}{ }^{\circ}$, a reaction scheme for which is given in Table 2 .

Table 2. Reaction scheme and rate constants for $\mathrm{NO}_{3} \cdot$ formation and decay pathways for the radiolysis of deaerated aqueous solutions of $\mathrm{NO}_{3}{ }^{-}$and $\mathrm{HNO}_{3}$.

\begin{tabular}{|c|c|c|c|}
\hline \multirow{2}{*}{ Number } & \multirow{2}{*}{ Reaction } & \multicolumn{2}{|c|}{$\begin{array}{l}\text { Rate Constant } \\
\left(\mathrm{dm}^{3} \mathrm{~mol}^{-1} \mathrm{~s}^{-1}\right)\end{array}$} \\
\hline & & $\begin{array}{l}\text { Model } \\
\text { (This work) }\end{array}$ & $\begin{array}{l}\text { Literature } \\
\text { (Ref) }\end{array}$ \\
\hline 2 (Table1) & $\mathrm{NO}_{3}^{-} m \mathrm{NO}_{3}^{-} * \rightarrow \mathrm{NO}_{3}{ }^{-}+\mathrm{e}^{-}$ & N/A & $\mathrm{N}^{\prime} \mathrm{A}^{5}$ \\
\hline 12 & $\mathrm{HNO}_{3}+\mathrm{OH}^{\cdot} \rightarrow \mathrm{NO}_{3}{ }^{-}+\mathrm{OH}^{-}$ & $1.9 \times 10^{7}$ & $5.3 \times 10^{712}$ \\
\hline 13 & $\mathrm{NO}_{3}{ }^{\cdot}+\mathrm{NO}_{3}^{\cdot} \rightarrow \mathrm{N}_{2} \mathrm{O}_{6}$ & $4.0 \times 10^{6}$ & $4.0 \times 10^{613}$ \\
\hline 14 & $\mathrm{NO}_{3}{ }^{-}+\mathrm{NO}_{2}^{-} \rightarrow \mathrm{NO}_{3}^{-}+\mathrm{NO}_{2}^{-}$ & $4.4 \times 10^{9}$ & $4.4 \times 10^{914}$ \\
\hline 15 & $\mathrm{NO}_{3}{ }^{\circ}+\mathrm{HNO}_{2} \rightarrow \mathrm{HNO}_{3}+\mathrm{NO}_{2}{ }^{\bullet}$ & $2.0 \times 10^{8}$ & $8.0 \times 10^{614}$ \\
\hline 16 & $\mathrm{NO}_{3}{ }^{\bullet}+\mathrm{NO}_{2}^{\cdot} \rightarrow \mathrm{N}_{2} \mathrm{O}_{5}$ & $1.1 \times 10^{9}$ & $1.0 \times 10^{913}$ \\
\hline 17 & $\mathrm{NO}_{3}{ }^{-}+\mathrm{H}_{2} \mathrm{O} \rightarrow \mathrm{HNO}_{3}+\mathrm{OH}^{\bullet}$ & $3.0 \times 10^{2}$ & $3.0 \times 10^{213}$ \\
\hline 18 & $\mathrm{NO}_{3}{ }^{\bullet}+\mathrm{OH}^{\cdot} \rightarrow \mathrm{NO}_{2}{ }^{-}+\mathrm{HO}_{2}^{\bullet}$ & $1.0 \times 10^{10}$ & $1.2 \times 10^{1015}$ \\
\hline 19 & $\mathrm{NO}_{3}{ }^{\cdot}+\mathrm{HO}_{2}{ }^{\cdot} \rightarrow \mathrm{HNO}_{3}+\mathrm{O}_{2}$ & $3.0 \times 10^{9}$ & $3.0 \times 10^{914}$ \\
\hline 20 & $\mathrm{NO}_{3}^{\cdot}+\mathrm{H}_{2} \mathrm{O}_{2} \rightarrow \mathrm{HNO}_{3}+\mathrm{HO}_{2}^{\cdot}$ & $7.1 \times 10^{6}$ & $7.1 \times 10^{6} 16$ \\
\hline
\end{tabular}

Systematic picosecond pulse radiolysis experiments have demonstrated that $\mathrm{NO}_{3}{ }^{\bullet}$ exhibits two key formation pathways. ${ }^{17,18}$

i. A fast formation pathway attributed to direct radiation effects on $\mathrm{NO}_{3}{ }^{-}$(2); although this fast component has been shown to conceal additional ultra-fast chemical processes such as 'dry hole' trapping $\left(\mathrm{H}_{2} \mathrm{O}^{\bullet+}+\mathrm{NO}_{3}{ }^{-} \rightarrow \mathrm{H}_{2} \mathrm{O}+\mathrm{NO}_{3}{ }^{\circ}\right)$, though further experimental evidence is required. ${ }^{19}$ Direct effect formation of $\mathrm{NO}_{3}{ }^{\cdot}$ is dependent upon the electron fraction of $\mathrm{NO}_{3}{ }^{-}$relative to water. ${ }^{20}$ Consequently, this pathway becomes significant at high $\mathrm{NO}_{3}{ }^{-}$concentrations $\left(>0.5 \mathrm{~mol} \mathrm{dm}{ }^{-3}\right){ }^{17,19}$

ii. A slow formation process involving the hydroxyl radical $\left(\mathrm{OH}^{\circ}\right)$ abstracting a proton from $\mathrm{HNO}_{3}$ (12). This process necessitates the presence of undissociated $\mathrm{HNO}_{3}$ $\left(\mathrm{HNO}_{3} \rightleftharpoons \mathrm{NO}_{3}{ }^{-}+\mathrm{H}^{+}\right)^{21}$ and thus is only viable in highly acidic solutions. 
Once formed, $\mathrm{NO}_{3}{ }^{\cdot}$ rapidly decays by reacting with water and other radiolytic species (e.g. reactions 13 to 20 in aqueous $\mathrm{NO}_{3}{ }^{-}$and $\mathrm{HNO}_{3}$ solutions), ultimately leading to the formation of secondary radiolysis products and complete consumption of $\mathrm{NO}_{3}{ }^{*}$ within microsecond timescales. However, there is still some uncertainty in the relative contributions of these $\mathrm{NO}_{3}{ }^{\circ}$ reactions. It was initially suggested that the main decay pathways of $\mathrm{NO}_{3}{ }^{\cdot}$ were via recombination (13) and/or reaction with $\mathrm{NO}_{2}{ }^{\bullet}(\mathbf{1 6}){ }^{14,22,23}$ Recombination of $\mathrm{NO}_{3}{ }^{\cdot}$ is unlikely as a significant decay pathway due to the reaction being very slow compared to other available routes, and the low probability of two $\mathrm{NO}_{3}{ }^{\cdot}$ radicals interacting within the radiation track relative to interacting with water or other radiolysis products. Although the reaction rate of $\mathrm{NO}_{3}{ }^{\circ}$ with $\mathrm{NO}_{2}{ }^{\circ}$ is sufficiently high, formation of $\mathrm{NO}_{2}{ }^{\circ}$ is purely by indirect effects (e.g. reactions 7 to 9,14 to 16 , and 18 ), and consequently can be expected to only become a significant decay pathway at later times, e.g. late nanosecond to early microsecond timescales. Hence, decay processes involving water and primary radiolysis products would be expected to dominate at shorter timescales (e.g. $\mathrm{OH}^{-}, \mathrm{H}_{2} \mathrm{O}_{2}, \mathrm{NO}_{2}{ }^{-}$, and $\mathrm{HNO}_{2}$ ). Pulse experiments performed by Katsumura et al. investigated the reaction of $\mathrm{NO}_{3}{ }^{*}$ with a number of scavenger species in $6 \mathrm{~mol} \mathrm{dm}{ }^{-3}$ aqueous $\mathrm{HNO}_{3}$ solution, including $\mathrm{H}_{2} \mathrm{O}_{2}$ and $\mathrm{HNO}_{2}{ }^{14}$ The rate constants for these scavenging reactions were adjusted to give the best fitting of experimental results. However, no quantitative mechanistic description has been provided thus far.

Hydrazinium $\left(\mathrm{N}_{2} \mathrm{H}_{5}{ }^{+}\right)$is commonly used as an anti-nitrous agent in spent nuclear fuel reprocessing solvent systems to rapidly react with nitrous acid $\left(\mathrm{HNO}_{2}\right)$ which is formed due to the instability of $\mathrm{HNO}_{3} .{ }^{24}$ The purpose of which is to inhibit $\mathrm{HNO}_{2}$ redox reactions with plutonium and other redox active metal ions, thereby promoting efficient extraction and product stream purity. ${ }^{25,26}$ In basic solution, hydrazine exist mainly as the $\mathrm{N}_{2} \mathrm{H}_{4}$ molecule.

However, in acidic solutions, hydrazine exists as up to two protonated hydrazinium ion forms, $\mathrm{N}_{2} \mathrm{H}_{5}{ }^{+}$and/or $\mathrm{N}_{2} \mathrm{H}_{6}{ }^{2+}$.

$$
\begin{array}{ll}
\mathrm{N}_{2} \mathrm{H}_{4}+\mathrm{H}^{+} \rightleftharpoons \mathrm{N}_{2} \mathrm{H}_{5}^{+} & \mathrm{pK}_{\mathrm{a} 1} \approx 7.9 \\
\mathrm{~N}_{2} \mathrm{H}_{5}^{+}+\mathrm{H}^{+} \rightleftharpoons \mathrm{N}_{2} \mathrm{H}_{6}{ }^{2+} & \mathrm{pK}_{\mathrm{a} 2} \approx-1
\end{array}
$$

Both protonated species present very different reactivity's towards $\mathrm{NO}_{3}{ }^{\circ}$, which leads to a number of mechanistic complexities. For example, in concentrated $\mathrm{HNO}_{3}$ solutions $\left(>6 \mathrm{~mol} \mathrm{dm}{ }^{-3}\right.$ ), two very different rate constants are given for the reaction of $\mathrm{N}_{2} \mathrm{H}_{5}{ }^{+}$with $\mathrm{NO}_{3}{ }^{\circ}$. 


$$
\begin{aligned}
\mathrm{N}_{2} \mathrm{H}_{5}{ }^{+}+\mathrm{NO}_{3}{ }^{-} \rightarrow \mathrm{N}_{2} \mathrm{H}_{4}{ }^{++}+\mathrm{NO}_{3}{ }^{-}+\mathrm{H}^{+} \quad \mathrm{k}_{23} & =1.3 \times 10^{9} \mathrm{dm}^{3} \mathrm{~mol}^{-1} \mathrm{~s}^{-1} 24 \\
\mathrm{k}_{23}{ }_{23} & =6.6 \times 10^{6} \mathrm{dm}^{3} \mathrm{~mol}^{-1} \mathrm{~s}^{-130}
\end{aligned}
$$

Furthermore, neither of these studies considered that both protonated forms of hydrazine could be present in solution at the same time in varying proportions, each of which possessing a different rate of reaction with $\mathrm{NO}_{3}{ }^{\cdot}$. This is further exacerbated as the acid dissociation constant for the second protonation reaction $\left(\mathrm{pK}_{\mathrm{a} 2}\right)$ is unclear, although some authors have proposed $\mathrm{pK}_{\mathrm{a} 2}$ values of approximately $-1 .^{31}$

The presented research evaluates the decay mechanism of $\mathrm{NO}_{3}{ }^{\cdot}$ in the absence and presence of hydrazine, from the radiolysis of deaerated $7 \mathrm{~mol} \mathrm{dm}^{-3}$ aqueous solutions of lithium nitrate $\left(\mathrm{LiNO}_{3}\right)$ and $\mathrm{HNO}_{3}$, by using a combination of pulse radiolysis and multi-scale modelling techniques to provide: (i) quantitative mechanistic insight into the decay pathways of $\mathrm{NO}_{3}{ }^{\circ}$; (ii) rate constants for the reactions of $\mathrm{N}_{2} \mathrm{H}_{5}{ }^{+}$and $\mathrm{N}_{2} \mathrm{H}_{6}{ }^{2+}$ with $\mathrm{NO}_{3}{ }^{\circ}$; (iii) the acid dissociation constant for the protonation of $\mathrm{N}_{2} \mathrm{H}_{5}^{+}\left(\mathrm{pK}_{\mathrm{a} 2}\right)$.

\section{METHODOLOGY}

\section{EXPERIMENT}

$\mathrm{LiNO}_{3}$ (Suprapur), $\mathrm{HNO}_{3}$ (Ultrapur and fresh), and $\mathrm{N}_{2} \mathrm{H}_{4}$ (Ultrapur) were supplied by Sigma Aldrich. All chemicals were used without further purification. Ultra-pure water $(18.2 \mathrm{M} \Omega \mathrm{cm})$ was used to make up all solutions. The solutions were bubbled with Ar to remove $\mathrm{O}_{2}$ and other gases. The experiments were performed at room temperature.

A transient absorption setup with a streak camera installed in experimental area EA-3 of the electron pulse facility ELYSE at Paris-Sud University was used. The electron beam irradiation was performed using the picosecond pulse radiolysis facility delivering a repetition rate of $5 \mathrm{~Hz}$, electron-pulses with an energy of $8 \mathrm{MeV}$. The dose deposited per pulse in the samples was deduced from the measurements of the transient absorbance of $\mathrm{e}_{\mathrm{aq}}{ }^{-}$ in water and verified just before each series of experiments. Typically, the electron pulse had a half width (FHWM) of $15 \mathrm{ps}$ and a charge of $\sim 6 \mathrm{nC}$. More details of the system configuration are described elsewhere. ${ }^{32,33}$ An optical quartz cell with an optical path length of $1 \mathrm{~cm}$ containing the sample was placed as close as possible to the output window of the electron beam to minimize divergence. Generally results are obtained from the average of 200 pulses (40 s for the measurements time). The solution from a stock of $200 \mathrm{~mL}$ is refreshed by using a peristaltic pump with a high flow rate of $200 \mathrm{~mL} \mathrm{~min}^{-1}$. The accumulated 
amount of $\mathrm{HNO}_{2}$ radiolytically produced in solution is very low because the volume of irradiation is only $120 \mu \mathrm{L}$, and $\mathrm{HNO}_{2}$ is diluted in $200 \mathrm{~mL}$, and the solution is deareated by Ar, which removes also $\mathrm{N}_{2} \mathrm{O}_{4}$.

\section{MULTI-SCALE MODELLING}

Multi-scale modelling was used to provide quantitative mechanistic analysis for the aforementioned experiments. The multi-scale modelling methodology is outlined in Figure 1. The multi-scale modelling approach relies on a combination of stochastic radiation track chemistry and deterministic kinetics models to provide a satisfactory description of the events occurring during the radiolysis of aqueous solutions. The model comprises four components which address the following four time regimes: track structure formation $(<1$ femtosecond); physicochemical processes $(<1$ picosecond); nonhomogeneous reaction kinetics (<1 microsecond), and; homogeneous bulk chemistry ( $>1$ microsecond).
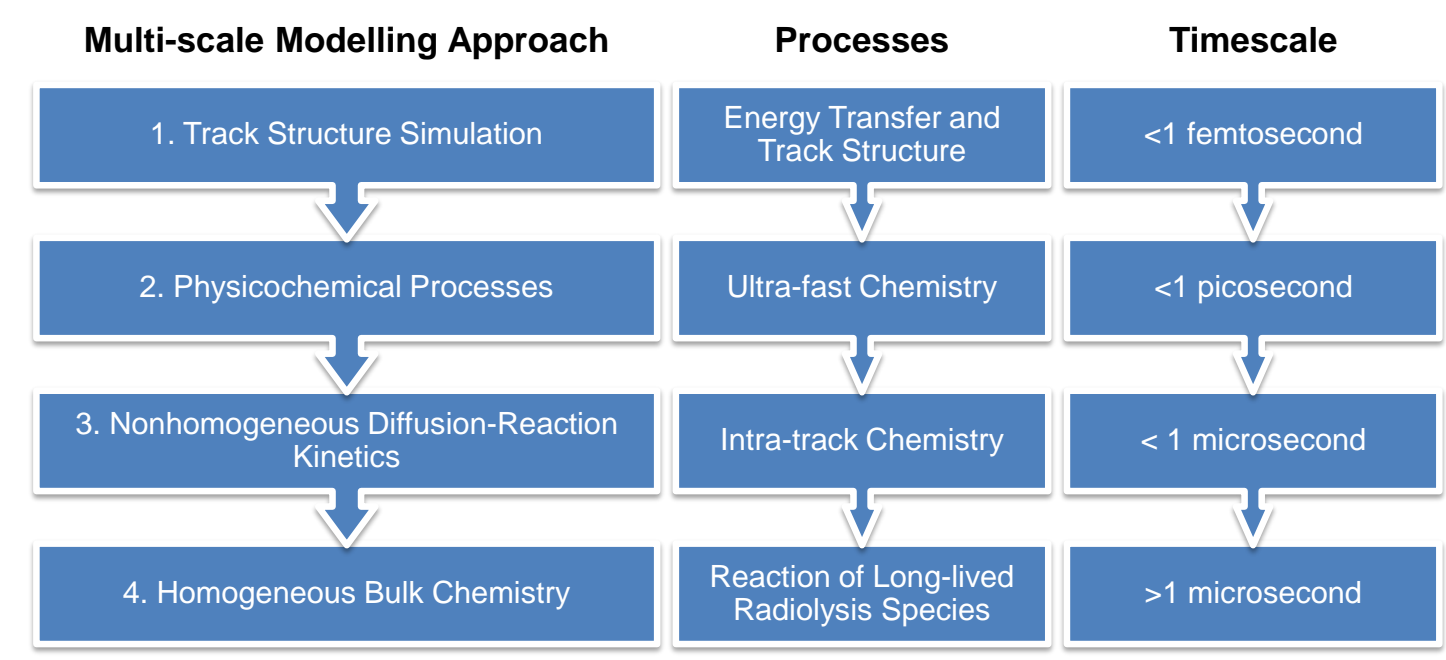

Figure 1. Schematic outline of the multi-scale modelling approach.

The stochastic component of the multi-scale model, stages 1 to 3 in Figure 1, uses well established radiation track structure formation and diffusion-kinetic independent reaction times models to simulate the physical and chemical processes occurring within a radiation track to a given time between the point of energy transfer up to the complete spatial relaxation of the radiation chemical track at about $1 \mu \mathrm{s}$ when the products of radiolysis can be considered to be homogeneously distributed in bulk solution. ${ }^{34-36}$ The stochastic component of the model provides radiolytic yields representative of the experimental system concerned at a given time regime, as initial parameters to allow the calculation of the formation rates of the products of radiolysis in the deterministic model. 
The deterministic model for bulk homogeneous radiation chemistry, stages 3 and 4 in Figure 1 , is based upon a more extensive reaction scheme than that listed in tables 1 and 2 , comprising water radiolysis reactions and reactions of $\mathrm{NO}_{3}{ }^{-} / \mathrm{HNO}_{3}$ and its radiation-induced product species. ${ }^{37}$ The chemistry is expressed as a set of coupled kinetic differential equations which were solved using the FACSIMILE software package. ${ }^{38}$ Both the stochastic and deterministic components of the multi-scale model are based on experimentally determined physical and chemical parameters. The multi-scale modelling formalism and these parameters have been described in detail elsewhere. ${ }^{37}$ The calculations presented in this research used stochastically calculated radiolytic yields corresponding to $10 \mathrm{~ns}$ after energy transfer by fast electron irradiation. The $10 \mathrm{~ns}$ transition point was selected on the basis of (i) being longer than the time taken for the majority significant scavenging processes to occur (i.e. more than 4 times longer than the half-lives for scavenging of $\mathrm{e}_{\mathrm{pre}}{ }^{-} / \mathrm{e}_{\mathrm{aq}}{ }^{-}$and $\mathrm{OH}^{\circ}$ by $\mathrm{NO}_{3}{ }^{-}$and $\mathrm{HNO}_{3}$, respectively), and (ii) because it coincides with the experimental time period after the electron pulse width at which measurements were taken. These radiolytic yields provide the indirect effect contribution to $\mathrm{NO}_{3}{ }^{\circ}$ formation and the concentrations of the other primary radiolysis species, which in conjunction with direct effects yields were corrected for the respective electron fractions of water and $\mathrm{NO}_{3}{ }^{-} / \mathrm{HNO}_{3}$ before being used as initial parameters in the deterministic model to simulate the radiolysis of deaerated aqueous $\mathrm{NO}_{3}{ }^{-} / \mathrm{HNO}_{3}$ solutions to $1 \mathrm{~ms}$, with time intervals of $100 \mathrm{~ns}$.

\section{RESULTS AND DISCUSSION}

Absorption Spectra of $\mathrm{NO}_{3}{ }^{\circ}$. The transient absorption spectra for $\mathrm{NO}_{3}{ }^{\cdot}$ measured in this work at $100 \mathrm{~ns}$ for deaerated aqueous $7 \mathrm{~mol} \mathrm{dm}^{-3} \mathrm{LiNO}_{3}$ and $\mathrm{HNO}_{3}$ solutions is given in Figure 2 . Both spectra show the characteristic three peaks absorption band for $\mathrm{NO}_{3}{ }^{\circ} ; 600,640$, and $680 \mathrm{~nm}$, in agreements with previous results but with higher spectral resolution obtained by the streak camera. ${ }^{14}$ 


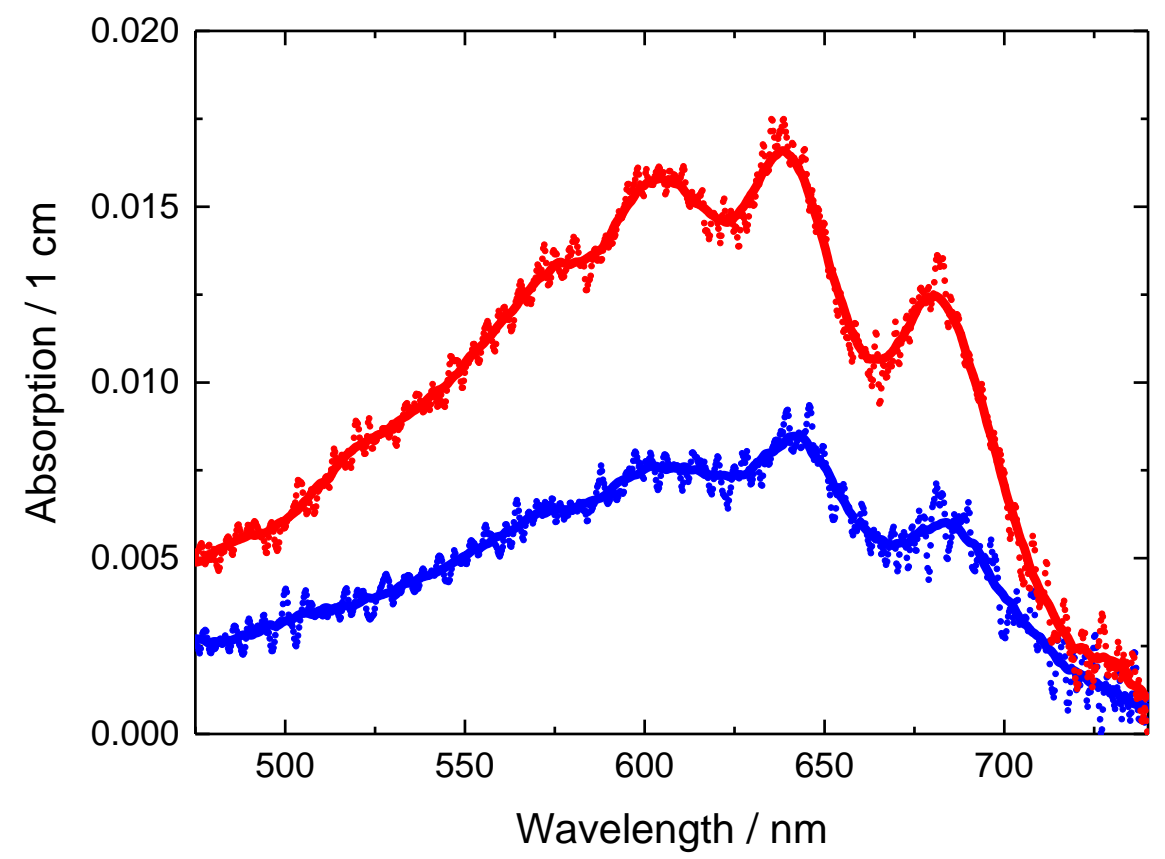

Figure 2. Transient absorption spectra of $\mathrm{NO}_{3}{ }^{\cdot}$ recorded at $100 \mathrm{~ns}$ after the electron pulse for deaerated (with Ar) aqueous $7 \mathrm{~mol} \mathrm{dm}{ }^{-3} \mathrm{LiNO}_{3}(-)$ and $7 \mathrm{~mol} \mathrm{dm}{ }^{-3} \mathrm{HNO}_{3}(-)$ solutions, at 38 Gy pulse ${ }^{-1}$.

Comparison of the two spectra clearly shows that the absorption intensity of $\mathrm{NO}_{3}{ }^{\cdot}$ from $\mathrm{HNO}_{3}$ is significantly greater than that from $\mathrm{LiNO}_{3}$, thus radiolysis of concentrated $\mathrm{HNO}_{3}$ solutions results in the formation of more $\mathrm{NO}_{3}{ }^{*}$, which is in agreement with previous findings

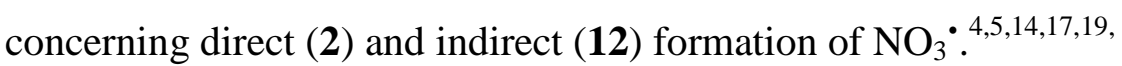

Decay Kinetics of $\mathrm{NO}_{3}{ }^{\cdot}$. The concentration and absorption of $\mathrm{NO}_{3}{ }^{\cdot}$ is given as a function of time and solution composition in Figure 3. Multi-scale modelling calculations provide predictions in good agreement with experiment. This agreement has been predominantly attained by changing the literature rate constants for two reactions:

i. The reaction rate of $\mathrm{OH}^{\bullet}$ with $\mathrm{HNO}_{3}(\mathbf{1 2})$ has been reported in the literature by Katsumura et al. as being $5.3 \times 10^{7} \mathrm{dm}^{3} \mathrm{~mol}^{-1} \mathrm{~s}^{-1}$, although initially reported as $1.4 \times 10^{8} \mathrm{dm}^{3} \mathrm{~mol}^{-1} \mathrm{~s}^{-1} .{ }^{14}$ The rate constant used in this work by fitting the experimental data was $1.9 \times 10^{7} \mathrm{dm}^{3} \mathrm{~mol}^{-1} \mathrm{~s}^{-1}$. This value is not in agreement with the two previously reported values. The rate of this process establishes the importance of indirect effect on $\mathrm{NO}_{3}{ }^{\cdot}$ formation $\left(\mathrm{G}\left(\mathrm{NO}_{3}{ }^{\circ}\right)_{\text {indirect }}=2.6\right.$ for $7 \mathrm{~mol} \mathrm{dm}{ }^{-3} \mathrm{HNO}_{3}$ determined by stochastic calculations at $10 \mathrm{~ns}$ ) and thus the initial yield of $\mathrm{NO}_{3}{ }^{\cdot}$ at 10 ns. The calculations performed for this research found that rate constants higher than 
$1.9 \times 10^{7} \mathrm{dm}^{3} \mathrm{~mol}^{-1} \mathrm{~s}^{-1}$ lead to significantly higher $\mathrm{NO}_{3} \cdot$ yields than those observed experimentally, with the extent of deviation increasing with decreasing $\mathrm{HNO}_{3}$ concentration; a consequence of relatively low $\mathrm{OH}^{\bullet}$ yield, progressively increasing undissociated $\mathrm{HNO}_{3}$ concentration, and the resultant effects on scavenging capacity of $\mathrm{HNO}_{3}$ for $\mathrm{OH}^{*}$. The rate constants reported by Katsumura et al. were determined using $\mathrm{HNO}_{3}$ dissociation data from Redlich et al. although their presented fractions of $\mathrm{HNO}_{3}$ dissociation are significantly lower than the literature data sets for $\mathrm{HNO}_{3}$ concentrations $\geq 4 \mathrm{~mol} \mathrm{dm}^{-3}$ ( $\sim 0.34 \mathrm{~mol} \mathrm{dm}^{-3}$ lower). Calculations presented here are based on $\mathrm{HNO}_{3}$ dissociation data from Davis and De Bruin ${ }^{21}$, of which there is little deviation between the two published $\mathrm{HNO}_{3}$ data sets for the $\mathrm{HNO}_{3}$ concentrations used in this work. $^{39,40}$

ii. The reaction rate of $\mathrm{NO}_{3}{ }^{\cdot}$ with $\mathrm{HNO}_{2}$ (15) was reported by Katsumura et al. as $8.0 \times 10^{6} \mathrm{dm}^{3} \mathrm{~mol}^{-1} \mathrm{~s}^{-1}$, determined by simulation and fitting to experimental results for $6 \mathrm{~mol} \mathrm{dm} \mathrm{HNO}_{3}$ solutions by the addition of $\mathrm{HNO}_{2}\left(2.3 \times 10^{-4}\right.$ and $\left.1.25 \times 10^{-3} \mathrm{~mol} \mathrm{dm}^{-3}\right){ }^{14}$ The rate constant used in this work was $2.0 \times 10^{8} \mathrm{dm}^{3} \mathrm{~mol}^{-1} \mathrm{~s}^{-1}$. The reaction scheme presented by Katsumura et al. is conservative at best, as it does not appear to incorporate any secondary chemistry for $\mathrm{HNO}_{2}$ (e.g. reaction with $\mathrm{OH}^{\cdot}, \mathrm{H}_{2} \mathrm{O}_{2}$ and $\mathrm{HNO}_{3}$ ), which ultimately deplete its concentration. Whereas the multi-scale modelling approach used here incorporates an extensive reaction scheme inclusive of secondary radiation induced reactions, which has been rigorously evaluated with regards to the radiolytic yields of $\mathrm{NO}_{2}{ }^{-}$and $\mathrm{HNO}_{2}$ for a wide range of $\mathrm{NO}_{3}{ }^{-}$and $\mathrm{HNO}_{3}$ concentrations $\left.\left(1 \times 10^{-3} \text { to } 6 \mathrm{~mol} \mathrm{dm}\right)^{-3}\right) ;^{37}$ consequently their secondary chemistry has been more satisfactorily incorporated. Hence, the higher rate constant used in our calculations accommodates for depletion of $\mathrm{HNO}_{2}$ by secondary chemistry, and is necessary to attain good agreement at longer timescales, i.e. $\geq 400 \mu$ s.

The initial yield of $\mathrm{NO}_{3}{ }^{\bullet}$ observed at $\sim 10 \mathrm{~ns}$ increases dramatically with increasing $\mathrm{HNO}_{3}$ concentration, although its decay kinetics slows leading to progressively longer lifetimes (up to milliseconds). These observations are most evident for the two extreme cases (neat $7 \mathrm{~mol}$ $\mathrm{dm}^{-3} \mathrm{LiNO}_{3(\mathrm{aq})}$ and $\mathrm{HNO}_{3(\mathrm{aq})}$ ), a quantitative mechanistic analysis for which is given in Figure 4. 


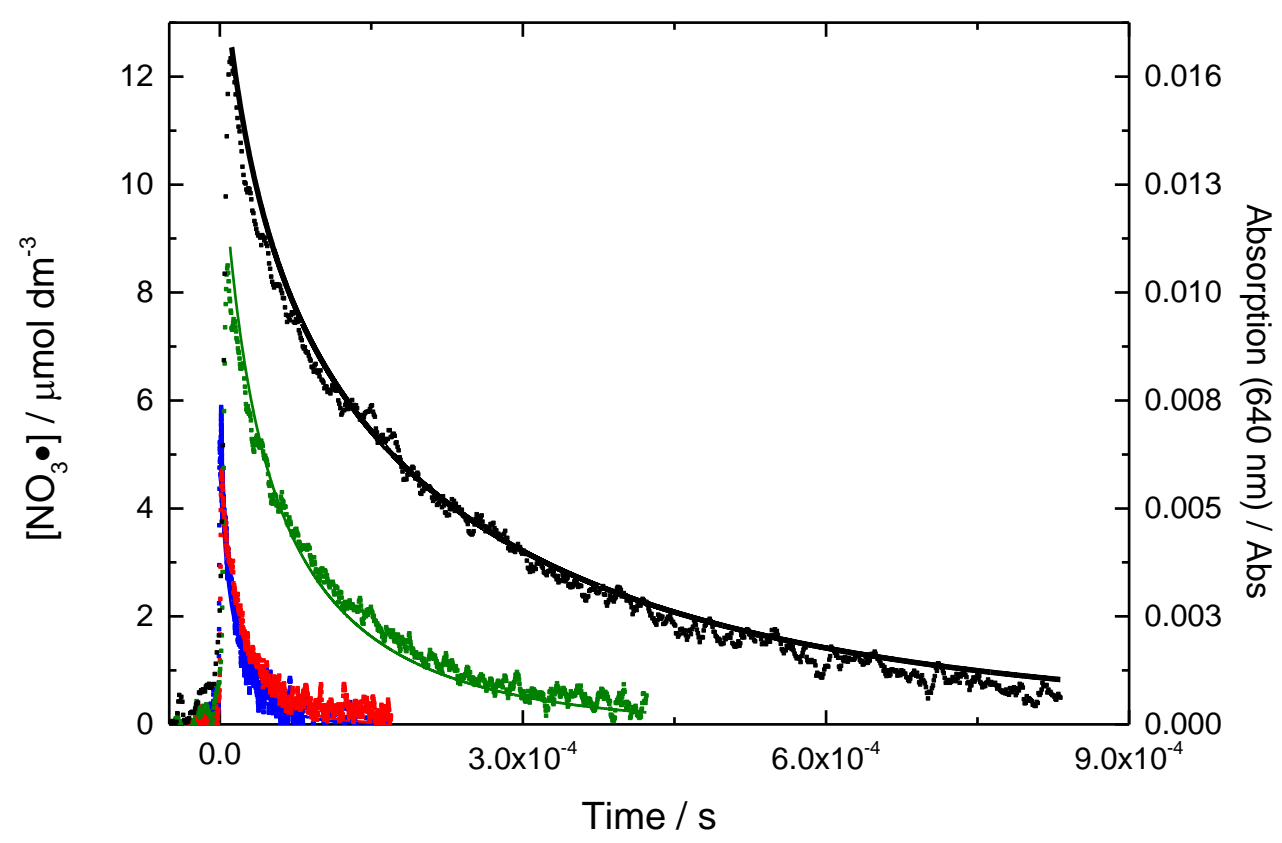

Figure 3. Concentration and absorption (at $640 \mathrm{~nm}$ ) of $\mathrm{NO}_{3}{ }^{\cdot}$ as a function of time from the radiolysis (38 Gy pulse ${ }^{-1}$ ) of deaerated: $7 \mathrm{~mol} \mathrm{dm}{ }^{-3} \mathrm{LiNO}_{3}(\mathbf{\Delta}), 7 \mathrm{~mol} \mathrm{dm}{ }^{-3} \mathrm{LiNO}_{3}+$ $1 \times 10^{-3} \mathrm{~mol} \mathrm{dm}^{-3} \mathrm{HNO}_{3}(\bullet), 6.9 \mathrm{~mol} \mathrm{dm}{ }^{-3} \mathrm{LiNO}_{3}+0.1 \mathrm{~mol} \mathrm{dm}{ }^{-3} \mathrm{HNO}_{3}(\boldsymbol{\nabla})$, and $7 \mathrm{~mol}$ $\mathrm{dm}^{-3} \mathrm{HNO}_{3}(\mathbf{\square})$; fitted lines are from multi-scale modelling calculations.

The formation of $\mathrm{NO}_{3}{ }^{-}$from the radiolysis of neutral aqueous $\mathrm{NO}_{3}{ }^{-}$solutions is purely by direct effects (1) and thus dependent upon the electron fraction of $\mathrm{NO}_{3}{ }^{-}$relative to water. In $7 \mathrm{~mol} \mathrm{dm}{ }^{-3} \mathrm{LiNO}_{3(\mathrm{aq})}$ solution (Figure 4 - top) the electron fraction of $\mathrm{NO}_{3}{ }^{-}$is approximately 0.28 , providing an initial $\mathrm{NO}_{3}{ }^{\cdot}$ concentration of $5.36 \times 10^{-6} \mathrm{~mol} \mathrm{dm}^{-3}$, the decay of which is completed within $160 \mu \mathrm{s}$. Note that the calculated concentrations are a function of dose $(\mathrm{Gy}=\mathrm{J}$ $\mathrm{kg}^{-1}$ ) and thus averaged over the cylindrical electron beam profile volume. According to our fits using the multi-scale modelling simulation code, the key processes responsible for this rapid decay involve the reaction of $\mathrm{NO}_{3}{ }^{-}$with $\mathrm{OH}^{\bullet}(37 \%), \mathrm{H}_{2} \mathrm{O}(29 \%), \mathrm{NO}_{2}^{-}(17 \%)$, and $\mathrm{NO}_{2}$ $(17 \%)$.

However, the formation of $\mathrm{NO}_{3}{ }^{\cdot}$ from the radiolysis of aqueous $\mathrm{HNO}_{3}$ is from direct (1) and indirect (2) effect pathways due to the presence of undissociated $\mathrm{HNO}_{3}$. Consequently, the initial concentration of $\mathrm{NO}_{3}{ }^{\cdot}$ in $7 \mathrm{~mol} \mathrm{dm}{ }^{-3} \mathrm{HNO}_{3(\mathrm{aq})}$ solution (Figure 4 - bottom) is $1.39 \times 10^{-5} \mathrm{~mol} \mathrm{dm}^{-3}$ at approximately $10 \mathrm{~ns}$, the decay of which is complete within approximately $1 \mathrm{~ms}$. The key processes responsible for this slower decay involve the reaction of $\mathrm{NO}_{3}{ }^{\circ}$ with $\mathrm{HNO}_{2}(15 \%)$ and $\mathrm{NO}_{2}(80 \%)$. 
The drastic shift in the importance of $\mathrm{NO}_{3} \cdot$ decay processes, in going from pure $\mathrm{LiNO}_{3(\mathrm{aq})}$ to pure $\mathrm{HNO}_{3(\mathrm{aq})}$, is due to the effect of lowering $\mathrm{pH}$ with increasing undissociated $\mathrm{HNO}_{3}$ concentration. As the fraction of $\mathrm{HNO}_{3}$ increases, the $\mathrm{pH}$ of the system decreases leading to a greater extent of undissociated $\mathrm{HNO}_{3}$ and $\mathrm{HNO}_{2}$. The implications of which are as follows:

i. There is progressively more undissociated $\mathrm{HNO}_{3}$ available for reaction with $\mathrm{OH}^{*}$ $\left(\sim 1.96 \mathrm{~mol} \mathrm{dm}^{-3} \text { in } 7 \mathrm{~mol} \mathrm{dm}{ }^{-3} \mathrm{HNO}_{3}\right)^{39,40}$

ii. Consumption of $\mathrm{OH}^{*}$ by $\mathrm{HNO}_{3}$ rapidly removes one of the key oxidising processes responsible for the rapid decay of $\mathrm{NO}_{3}{ }^{\circ}$ in pure $\mathrm{LiNO}_{3(\mathrm{aq})}$ solutions. However, this process has further implications, as it establishes an equilibrium with the reaction of $\mathrm{NO}_{3}{ }^{\bullet}$ with $\mathrm{H}_{2} \mathrm{O}(17)$ at timescales $>10 \mathrm{~ns} ; \mathrm{HNO}_{3}+\mathrm{OH}^{\bullet} \rightleftharpoons \mathrm{NO}_{3}{ }^{\bullet}+\mathrm{H}_{2} \mathrm{O}$. Although this equilibrium lies in favour of $\mathrm{NO}_{3}{ }^{\cdot}$ and $\mathrm{H}_{2} \mathrm{O}$ formation $\left(2.54 \times 10^{-7} \mathrm{~mol} \mathrm{dm}{ }^{-3}\right)$, the process ultimately removes the importance of two key $\mathrm{NO}_{3} \cdot$ decay processes in $\mathrm{HNO}_{3(\mathrm{aq})}$ solution.

iii. Formation of $\mathrm{HNO}_{2}\left(\mathrm{HNO}_{2} \rightleftharpoons \mathrm{NO}_{2}^{-}+\mathrm{H}^{+}, \mathrm{pK}_{\mathrm{a}}=3.2\right)$ also reduces the rate at which $\mathrm{NO}_{3}{ }^{\cdot}$ decays, relative to $\mathrm{NO}_{3}{ }^{-}$solutions. This is because $\mathrm{HNO}_{2}$ is less reactive towards $\mathrm{NO}_{3} \cdot\left(\mathrm{k}_{15}=2.0 \times 10^{8} \mathrm{dm}^{3} \mathrm{~mol}^{-1} \mathrm{~s}^{-1}\right)$. Furthermore, $\mathrm{HNO}_{2}$ is more reactive towards other water and $\mathrm{NO}_{3}{ }^{-} / \mathrm{HNO}_{3}$ radiolysis products (e.g. $\mathrm{OH}^{*}, \mathrm{H}_{2} \mathrm{O}_{2}$, and $\mathrm{HNO}_{2}$ ), relative to $\mathrm{NO}_{2}^{-}$. Consequently, there is effectively less $\mathrm{HNO}_{2}$ available to undergo reaction with $\mathrm{NO}_{3}{ }^{\circ}$. 

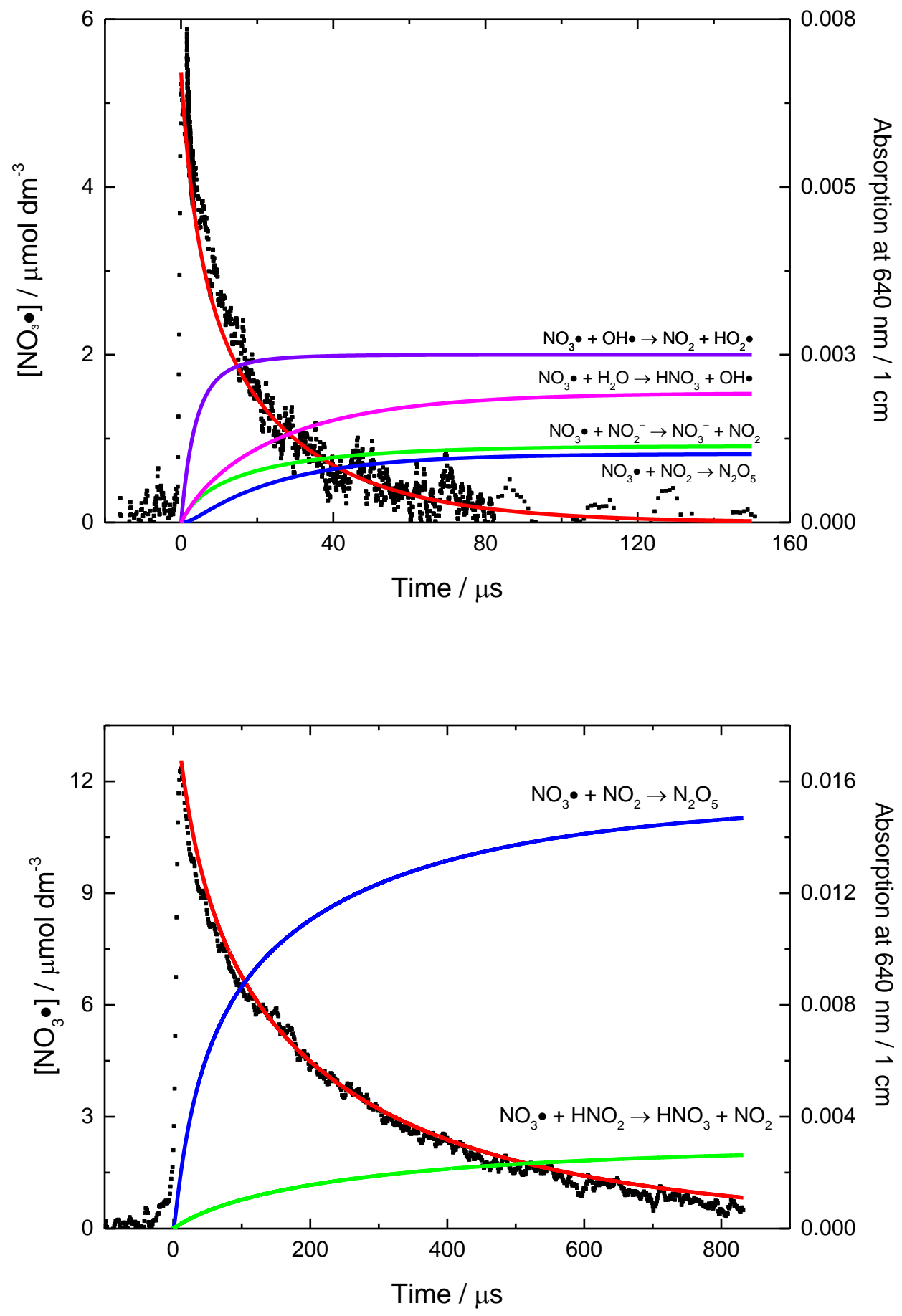

Figure 4. (top) Concentration and absorption of $\mathrm{NO}_{3}{ }^{\circ}$ as a function of time from the radiolysis (38 Gy pulse ${ }^{-1}$ ) of deaerated $7 \mathrm{~mol} \mathrm{dm}^{-3} \mathrm{LiNO}_{3}$ solution: Experiment (ם); Multiscale model calculation (-); Predicted concentration of $\mathrm{NO}_{3}{ }^{-}$consumed by $\mathrm{NO}_{2}(16), \mathrm{NO}_{2}{ }^{-}$ (14), $\mathrm{OH}^{\cdot}$ (18), and $\mathrm{H}_{2} \mathrm{O}$ (17). (bottom) Concentration and absorption of $\mathrm{NO}_{3}{ }^{\cdot}$ as a function of time from the radiolysis ( $38 \mathrm{~Gy}$ pulse ${ }^{-1}$ ) of deaerated 7 mol $\mathrm{dm}^{-3} \mathrm{HNO}_{3}$ solution: Experiment (ם); Multi-scale model calculation (-); Predicted concentration of $\mathrm{NO}_{3}{ }^{\cdot}$ produced by reaction of $\mathrm{OH}^{*}$ with $\mathrm{HNO}_{3}$; Predicted concentration of $\mathrm{NO}_{3}{ }^{\circ}$ consumed by $\mathrm{NO}_{2}$ (16), and $\mathrm{HNO}_{2}$ (15). 
iv. The drastic increase in the importance of the $\mathrm{NO}_{2}{ }^{-}$decay pathway (16) arises from the increased availability of $\mathrm{NO}_{3} \cdot$ due to the 'inhibition' of $\mathrm{OH}^{\cdot}$ and $\mathrm{H}_{2} \mathrm{O}$ decay pathways, and the reduced concentration $\mathrm{HNO}_{2}$ and its lower reactivity towards $\mathrm{NO}_{3}{ }^{\circ}$.

Reactivity of $\mathrm{NO}_{3}{ }^{\cdot}$ with hydrazine. The reactivity of $\mathrm{NO}_{3}{ }^{\cdot}$ with the hydrazine molecule and hydrazinium ions, was studied for four aqueous solutions containing a constant $7 \mathrm{~mol} \mathrm{\textrm {dm } ^ { - 3 }}$ concentration of $\mathrm{NO}_{3}{ }^{-}$and an increasing concentration of $\mathrm{H}_{\mathrm{aq}}{ }^{+}(0.1,1.0,3.0$; and $7.0 \mathrm{~mol} \mathrm{dm}{ }^{-3} \mathrm{HNO}_{3}$ ). Figure 5 shows the change in $\mathrm{NO}_{3}{ }^{\circ}$ absorption at $640 \mathrm{~nm}$ for $7 \mathrm{~mol} \mathrm{dm}-$ ${ }^{3} \mathrm{HNO}_{3}$ in the presence of several total hydrazine concentrations $\left([\mathrm{NH}]_{\text {Total }}\right)$, defined as follows:

$$
[\mathrm{NH}]_{\text {Total }}=\left[\mathrm{N}_{2} \mathrm{H}_{4}\right]+\left[\mathrm{N}_{2} \mathrm{H}_{5}^{+}\right]+\left[\mathrm{N}_{2} \mathrm{H}_{6}{ }^{2+}\right]
$$

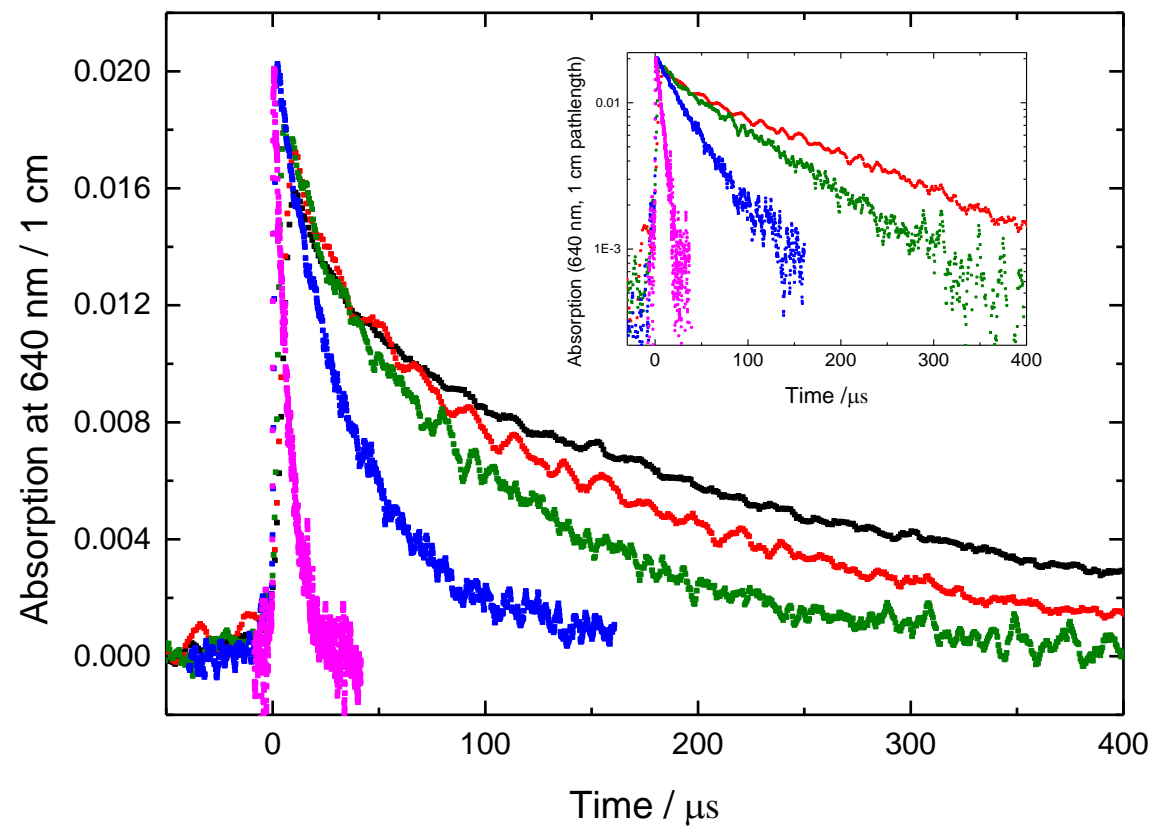

Figure 5. Absorption of $\mathrm{NO}_{3}{ }^{\circ}$ at $640 \mathrm{~nm}$ as a function of time from the radiolysis (40 Gy pulse ${ }^{-1}$ ) of deaerated: $7 \mathrm{~mol} \mathrm{dm}{ }^{-3} \mathrm{HNO}_{3}$ without hydrazine (ם), $7 \mathrm{~mol} \mathrm{dm}{ }^{-3} \mathrm{HNO}_{3}+$ $2 \times 10^{-4} \mathrm{~mol} \mathrm{dm}^{-3} \mathrm{NH}_{\mathrm{Tot}}(\bullet), 7 \mathrm{~mol} \mathrm{dm}^{-3} \mathrm{HNO}_{3}+1 \times 10^{-3} \mathrm{~mol} \mathrm{dm}^{-3} \mathrm{NH}_{\mathrm{Tot}}(\boldsymbol{\Delta}), 7 \mathrm{~mol}$ $\mathrm{dm}^{-3} \mathrm{HNO}_{3}+1 \times 10^{-2} \mathrm{~mol} \mathrm{dm}{ }^{-3} \mathrm{~N}_{2} \mathrm{H}_{4}(\nabla)$, and $7 \mathrm{~mol} \mathrm{dm}{ }^{-3} \mathrm{HNO}_{3}+0.1 \mathrm{~mol} \mathrm{dm}^{-3} \mathrm{NH}_{\mathrm{Tot}}$ $(\diamond)$.Inset: Example decay in the logarithm scale for the absorbance of $\mathrm{NO}_{3}{ }^{\cdot}$ as function of time for deaerated aqueous $7 \mathrm{~mol} \mathrm{dm}{ }^{-3} \mathrm{HNO}_{3}$ solution in the presence of a total hydrazine concentration $\left([\mathrm{NH}]_{\text {Total }}\right)$.

Given that the acid dissociation constant for $\mathrm{N}_{2} \mathrm{H}_{4} / \mathrm{N}_{2} \mathrm{H}_{5}{ }^{+}$is 7.9 , the amount of $\mathrm{N}_{2} \mathrm{H}_{4}$ present under the investigated conditions is negligible. Consequently, the decay kinetics of $\mathrm{NO}_{3}{ }^{\circ}$ in the presence of a given hydrazine concentration takes the following form: 


$$
\frac{-d\left[\mathrm{NO}_{3}^{\bullet}\right]}{d t}=k_{\text {overall }}\left[N O_{3}^{\bullet}\right]+\left[\left(k_{N_{2} H_{5}^{+}}\left[N_{2} H_{5}^{+}\right]\left[N O_{3}^{\bullet}\right]\right)+\left(k_{N_{2} H_{6}{ }^{2+}}\left[N_{2} H_{6}{ }^{2+}\right]\left[N O_{3}^{\bullet}\right]\right)\right]
$$

The first term of the decay stands for the decay in the absence of hydrazine with an overall rate constant of $k_{\text {overall. }}$ Equation (25) can be expressed as:

$$
\frac{-d\left[\mathrm{NO}_{3}^{\bullet}\right]}{d t}=k_{\text {overall }}\left[\mathrm{NO}_{3}^{\bullet}\right]+\left(k_{\text {obs }}[\mathrm{NH}]_{\text {Total }}\left[\mathrm{NO}_{3}^{\bullet}\right]\right)=\left(k_{\text {overall }}+k_{\text {obs }}[\mathrm{NH}]_{\text {Total }}\right)\left[\mathrm{NO}_{3}^{\bullet}\right]
$$

with

$$
\begin{gathered}
k_{o b s}=\frac{k_{N_{2} H_{5}^{+}}+k_{N_{2} H_{6}^{2+}}\left[H^{+}\right] \times K_{a 2}}{1+K_{a 2}\left[H^{+}\right]}, \\
K_{a 1}=\left(\frac{\left[N_{2} H_{5}^{+}\right]}{\left[N_{2} H_{4}\right]\left[H^{+}\right]}\right),
\end{gathered}
$$

and

$$
K_{a_{2}}=\left(\frac{\left[N_{2} H_{6}^{2+}\right]}{\left[N_{2} H_{5}^{+}\right]\left[H^{+}\right]}\right) .
$$

Considering that the amount of hydrazine is larger than the $\mathrm{NO}_{3}{ }^{\circ}$, it is possible to consider the reaction as a pseudo-first order reaction by plotting the logarithm of the absorbance of $\mathrm{NO}_{3}{ }^{\circ}$ as a function of time. The slope of linear variation of logarithm of absorbance decay of $\mathrm{NO}_{3}{ }^{\circ}$ with time corresponds to the value $\mathrm{k}_{\mathrm{obs}}[\mathrm{NH}]_{\text {tot }}$ (Figure 5 - inset). From these kinetic spectra the value of $\mathrm{k}_{\mathrm{obs}}$ can be deduced for each acidic solution containing different concentration of total hydrazine (Figure 6 and 7). In order to avoid direct radiolysis of hydrazine, the maximum concentration considered was $7 \times 10^{-2} \mathrm{~mol} \mathrm{dm}^{-3}$. For example, when the concentration of $\mathrm{HNO}_{3}$ is $7 \mathrm{~mol} \mathrm{dm}{ }^{-3}, \mathrm{k}_{\mathrm{obs}}=1.6( \pm 0.2) \times 10^{6} \mathrm{dm}^{3} \mathrm{~mol}^{-1} \mathrm{~s}^{-1}$ (Figure 6). 


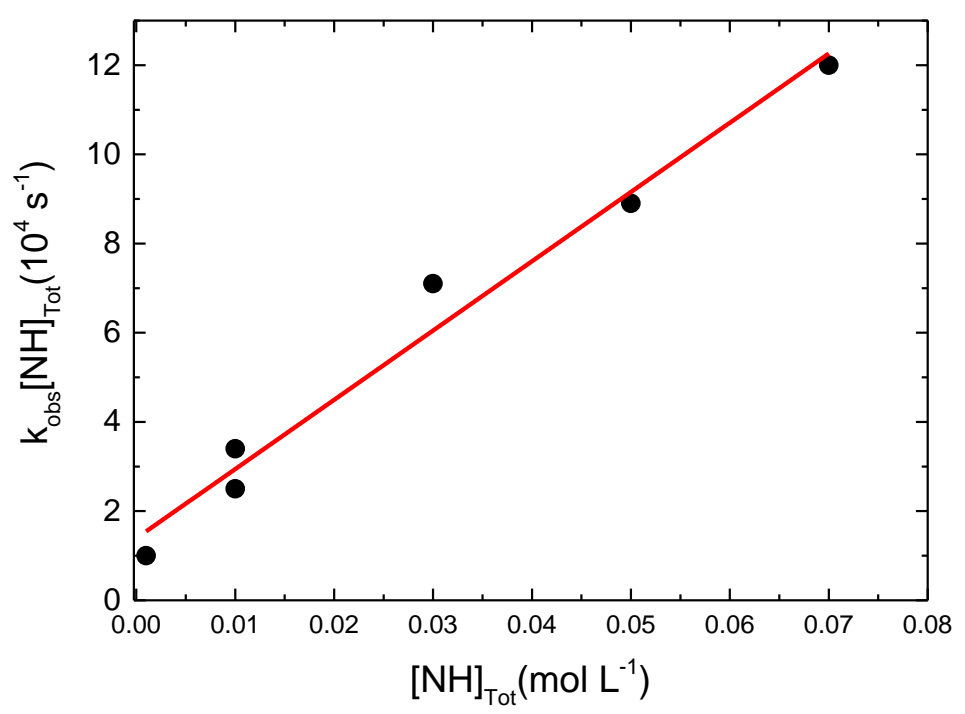

Figure 6. Variation of $\mathrm{k}_{\mathrm{obs}}$ with $[\mathrm{NH}]_{\text {Total }}$ for argon purged aqueous $7 \mathrm{~mol} \mathrm{dm}{ }^{-3} \mathrm{HNO}_{3}$ solutions; (40 Gy pulse ${ }^{-1}$ ).

The methodology for determining $\mathrm{k}_{\mathrm{obs}}$ was applied to other acid concentrations $\left(\left[\mathrm{H}^{+}\right]=0.1\right.$ mol dm${ }^{-3} ; 1.0 \mathrm{~mol} \mathrm{dm}^{-3}$ and $3.0 \mathrm{~mol} \mathrm{dm}^{-3}$ ) at $7 \mathrm{~mol} \mathrm{dm}^{-3}$ total $\mathrm{NO}_{3}{ }^{-}$with $0.001 \mathrm{~mol} \mathrm{dm}^{-3}<$ $[\mathrm{NH}]_{\text {Total }}<0.07 \mathrm{~mol} \mathrm{dm}{ }^{-3}$. In these conditions, the solutions consist of a mixture $\mathrm{HNO}_{3}-$ $\mathrm{LiNO}_{3}$ but there is no data in the literature on the acid dissociation for high concentration of nitrate ions. It was therefore decided to use an arbitrary constant value of dissociation of the nitric acid, which adjusts the free acidity data available in the literature. ${ }^{39,40}$ An acidity constant of 12.9 was used. From these kinetic results the value of $\mathrm{k}_{\mathrm{obs}}$ can be deduced for each acidic solution containing different concentration of total hydrazine.

The variation of $\mathrm{k}_{\mathrm{obs}}$ in function of the free acidity is shown in Figure 7. This variation of $\mathrm{k}_{\mathrm{obs}}$ solves the equation (27) and determines the kinetic constants $\mathrm{k}_{\mathrm{N}_{2} \mathrm{H}_{5^{+}}}$and $\mathrm{k}_{\mathrm{N}_{2} \mathrm{H}_{6}{ }^{2+}}$ and $\mathrm{K}_{\mathrm{a} 2}$.

According to the observed kinetics it is found that $\mathrm{k}_{\mathrm{N}_{2} \mathrm{H}_{5^{+}}}=2.9( \pm 0.9) \times 10^{7} \mathrm{dm}^{3} \mathrm{~mol}^{-1} \mathrm{~s}^{-1}$, $\mathrm{k}_{\mathrm{N}_{2} \mathrm{H}_{6} 2+}=1.3( \pm 0.3) \times 10^{6} \mathrm{dm}^{3} \mathrm{~mol}^{-1} \mathrm{~s}^{-1}$, and $\mathrm{K}_{\mathrm{a}_{2}}=10( \pm 4)$. The value of the $\mathrm{K}_{\mathrm{a}_{2}}$ in the literature is 11.2 for hydrazinium protonation which is close to that found here by measuring the kinetics in different solutions. ${ }^{27}$ 


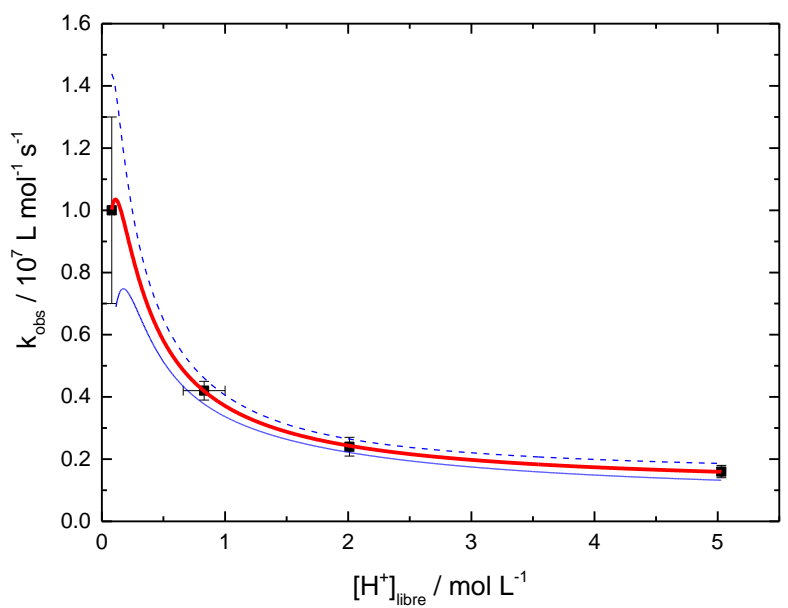

Figure 7. Variation of experimental $\mathrm{k}_{\mathrm{obs}}$ with free acid concentration for a medium containing deaerated solution of $7 \mathrm{~mol} \mathrm{dm}^{-3}$ total $\mathrm{NO}_{3}{ }^{-}$; $\left(40 \mathrm{~Gy}\right.$ pulse $\left.{ }^{-1}\right)$. The data are fitted (solid line) from modelling calculations and dotted lines are uncertainty. 


\section{CONCLUSIONS}

The detailed decay mechanism of $\mathrm{NO}_{3}{ }^{\circ}$ has been determined through a combination of experiment and calculation for $7 \mathrm{~mol} \mathrm{dm}{ }^{-3}$ solutions of deaerated aqueous $\mathrm{LiNO}_{3}$ and $\mathrm{HNO}_{3}$, in the absence and presence of hydrazine. In the absence of hydrazine, the predominant $\mathrm{NO}_{3}{ }^{\circ}$ decay pathways are strongly dependent upon the $\mathrm{pH}$ of the solution. For neat neutral $\mathrm{pH}$ $\mathrm{LiNO}_{3}\left(7 \mathrm{~mol} \mathrm{dm}{ }^{-3}\right)$ solutions, $\mathrm{NO}_{3}{ }^{*}$ is rapidly consumed by $\mathrm{OH}^{\bullet}(37 \%), \mathrm{H}_{2} \mathrm{O}(37 \%), \mathrm{NO}_{2}{ }^{-}$ $(17 \%)$, and $\mathrm{NO}_{2}(17 \%)$. As the acidity increase with increasing $\mathrm{HNO}_{3}$ fraction, there is a greater degree of undissociated $\mathrm{HNO}_{3}$ which strongly influences the $\mathrm{NO}_{3} \cdot$ decay pathways. For neat $\mathrm{HNO}_{3}\left(7 \mathrm{~mol} \mathrm{dm}{ }^{-3}\right)$ solutions, $\mathrm{NO}_{3}{ }^{-}$is rapidly consumed by $\mathrm{HNO}_{2}(15 \%)$ and $\mathrm{NO}_{2}$ $(80 \%)$.

In the presence of hydrazine, $\mathrm{NO}_{3}{ }^{\cdot}$ is rapidly consumed by $\mathrm{N}_{2} \mathrm{H}_{5}{ }^{+}$, and $\mathrm{N}_{2} \mathrm{H}_{6}{ }^{2+}$, once again exhibiting a pH dependence. The rate constants were found to be $\mathrm{k}_{\mathrm{N}_{2} \mathrm{H}_{5^{+}}}=2.9( \pm 0.9) \times 10^{7}$ $\mathrm{dm}^{3} \mathrm{~mol}^{-1} \mathrm{~s}^{-1}, \mathrm{k}_{\mathrm{N}_{2} \mathrm{H}_{6}{ }^{2+}}=1.3( \pm 0.3) \times 10^{6} \mathrm{dm}^{3} \mathrm{~mol}^{-1} \mathrm{~s}^{-1}$.

\section{AUTHOR INFORMATION}

Corresponding Author:

*E-mail: mehran.mostafavi@u-psud.fr; Tel: 33169157887.

Notes:

The authors declare no competing financial interest.

\section{ACKNOWLEDGEMENTS}

This research has been funded by AREVA N.C., the Engineering and Physical Sciences Research Council (EPSRC) and the Dalton Cumbrian Facility project, a joint initiative of the Nuclear Decommissioning Authority (NDA) and The University of Manchester. G. P. Horne was supported by a studentship from the EPSRC Nuclear FiRST Doctoral Training Centre at The University of Manchester. 


\section{REFERENCES}

(1) Mincher, B. J., Modolo, G., and Mezyk, S. P., Review Article: The Effects of Radiation Chemistry on Solvent Extraction: 1. Conditions in Acidic Solution and a Review of TBP Radiolysis. Solv. Extr. Ion Exch., 2009, 27, 1-25.

(2) Whillock, G. O. H., and Worthington, S. E., Shreir's Corrosion Volume 2, Elsevier, Amsterdam, 2010.

(3) Moyer, B, A., Ion Exchange and Solvent Extraction a Series of Advances Volume 19, CRC Press, Boca Raton, 2010.

(4) Katsumura, Y., N-Centered Radicals, the Chemistry of Free Radicals, John Wiley \& Sons, 1998.

(5) Jiang, P.Y., Nagaishi, R., Yotsuyanagi, T., Katsumura, Y., and Ishigure, K., $\gamma$-Radiolysis Study of Concentrated Nitric Acid Solutions. J. Chem. Soc. Faraday Trans., 1994, 90, 93-95.

(6) Pimblott, S. M., and LaVerne, J. A., On the Radiation Chemical Kinetics of the Precursor to the Hydrated Electron. J. Phys. Chem. A, 1998, 102, 2967-2975.

(7) Buxton, G. V., Greenstock, C. L., Helman, W. P., and Ross, A. B., Critical Review of rate constants for reactions of hydrated electrons, hydrogen atoms and hydroxyl radicals $(\cdot \mathrm{OH} / \cdot \mathrm{O}-$ in Aqueous Solution. J. Phys. Chem. Ref. Data, 1988, 17, 513-886.

(8) Logager and Sehested, Formation and decay of peroxynitrous acid: a pulse radiolysis study, $J$. Phys. Chem., 1993, 97, 6664-6669.

(9) Graetzel, M., Henglein, A., and Taniguchi, S., Pulsradiolytische Beobachtungen über die Reduktion des $\mathrm{NO}_{3}^{-}$-Ions und über Bildung und Zerfall der persalpetrigen Säure in wäßriger Lösung. Ber. Bunsenges. Phy. Chem., 1970, 74, 292-298.

(10) Graetzel, M., Henglein, A., Lilie, J., and Beck, G., Pulsradiolytische Untersuchung einiger Elementarprozesse der Oxydation und Reduktion des Nitritions. Ber. Bunsenges. Phy. Chem., 1969, 73, 646-653.

(11) Lammel, G., Perner, D., and Warneck, P., Decomposition of pernitric acid in aqueous solution. J. Phys. Chem., 1990, 94, 6141-6144.

(12) Jiang P. ; Katsumura, Y.; Ishigure, K. ; Yoshida, Y. Reduction potential of the nitrate radical in aqueous solution. Inorg. Chem., 1992, 31, 5135-5136.

(13) Poskrebyshev et al, Equilibrium constant of the reaction $\cdot \mathrm{OH}+\mathrm{HNO}_{3} \leftrightarrows \mathrm{H}_{2} \mathrm{O}+\mathrm{NO}_{3}$. in aqueous solution. J. Geophys. Res., 2001, 106, 4995-5004.

(14) Katsumura, Y., Jiang, P. Y., Nagaishi, T., Oishi, T., Ishigure, K., and Yoshida, Y., Pulse radiolysis study of aqueous nitric acid solutions: formation mechanism, yield, and reactivity of $\mathrm{NO}_{3}$ radical. J. Phys. Chem., 1991, 95, 4435-4439.

(15) Whittman, R., Radiolysis Model Sensitivity Analysis for a Used Fuel Storage Canister - Fuel Cycle Research \& Development, FCRD-UFD-2013-000357 PNNL-22773, 2013.

(16) Herrmann et al, Reactivity trends in reactions of the nitrate radical $\left(\mathrm{NO}_{3}\right)$ with inorganic and organic cloudwater constituents. Geochim. Cosmochim. Acta., 1994, 58, 3239-3244.

(17) Daniels, Radiation chemistry of the aqueous nitrate system. III. Pulse electron radiolysis of concentrated sodium nitrate solutions. J. Phys. Chem., 1969, 73, 3710-3717.

(18) Broszkiewicz, R. K., The radiation-induced formation of $\mathrm{NO}_{3}$ in aqueous solutions. Int. J. Appl. Radiat. Isot., 1967, 18, 25-32.

(19) Balcerzyk, A., El Omar, A. K., Schmidhammer, U., Pernot, P., and Mostafavi, M., Picosecond Pulse Radiolysis Study of Highly Concentrated Nitric Acid Solutions: Formation Mechanism of $\mathrm{NO}_{3}{ }^{\circ}$ Radical. J. Phys. Chem. A, 2012, 116, 7302-7307.

(20) Swallow, A. J., and Inokuti, M., Radiation-energy partition among mixture components: Current ideas on an old question. Radiat. Phys. Chem., 1988, 32, 185-189.

(21) Davis, W., and De Bruin, H. J., New activity coefficients of $0-100$ per cent aqueous nitric acid. J. Inorg. Nucl. Chem., 1964, 26, 1069-1083.

(22) Neta, P., and Huie, R. E., Rate constants for reactions of nitrogen oxide $\left(\mathrm{NO}_{3}\right)$ radicals in aqueous solutions. J. Phys. Chem., 1986, 90, 4644-4648. 
(23) Wine, P. H., Mauldin, R. L., and Thorn, R. P., Kinetics and spectroscopy of the nitrogen oxide radical $\left(\mathrm{NO}_{3}\right)$ in aqueous ceric nitrate-nitric acid solutions. J. Phys. Chem., 1988, 92, 11561162.

(24) Belova, E. V., and Egorov, G. F., Radiochemical behaviour of hydrazine nitrate in aqueous nitric acid solutions. Atomic Energy, 1997, 83, 622-626.

(25) Dukes, E. K., Kinetics and Mechanisms for the Oxidation of Trivalent Plutonium by Nitrous Acid. J. Am. Chem. Soc., 1960, 82, 9-13.

(26) Wick, O. J., Plutonium Handbook - A Guide to the Technology Volumes 1 and 2, American Nuclear Society, Illinois, 1980.

(27) Schmidt E. W., Hydrazine and its Derivatives: Preparation, Properties, Applications Volume 1, $2^{\text {nd }}$ Edition, Wiley-Interscience, New Jersey, 1984.

(28) Ware, G. C., Spulnik, J. B., and Gilbert, E. C., The Ionization Constant of Hydrazinium Hydroxide. J. Am. Chem. Soc., 1936, 58, 1605-1606.

(29) Schwarzenbach, G., Die Dissoziationskonstanten des Hydrazins. Hel. Chim. Acta., 1936, 19, 178-182.

(30) Protzaova, E. L., and Khaikin G. I., Nitrogen Trioxide in Irradiated Aqueous Nitric Acid Solutions of Hydrazine. High Energy. Chem., 2001, 35, 219-223.

(31) Pratt, L., and Richards, R. E., Proton magnetic resonance spectra of hydrazine salts. Part. Trans. Faraday. Soc., 1953, 49, 744-751.

(32) Belloni, J., Manard, H., Larbre, J.-P., Demarque, A., De Waele, V., Lampre, I., Marignier, J.L., Mostafavi, M., Bourdon, J. C., Bernard, M., et al. ELYSE-A picosecond electron accelerator for pulse radiolysis. Instr. Meth. Phys. Res. A, 2005, 539, 527-539.

(33) Marignier, J.-L., de Waele, V., Monard, H., Gobert, F., Larbre, J.-P., Demarque, A., Mostafavi, M., and Belloni, J., Time-resolved spectroscopy at the picosecond laser-triggered electron accelerator ELYSE. Rad. Phys. Chem., 2006, 75, 1024-1033.

(34) Pimblott, S.M., LaVerne, J. A., and Mozumder, A., Monte Carlo Simulation of Range and Energy Deposition by Electrons in Gaseous and Liquid Water. J. Phys. Chem., 1996, 100, 8595-8606.

(35) Pimblott, S.M., and LaVerne, J. A., Effects of Track Structure on the Ion Radiolysis of the Fricke Dosimeter. J. Phys. Chem. A, 2002, 106, 9420-9427.

(36) Clifford, P., Green, N. J, B., Oldfield, M. J., Pilling, M. J., and Pimblott, S. M., Stochastic models of multi-species kinetics in radiation-induced spurs. J. Chem. Soc., Faraday Trans., 1986, 82, 2673-2689.

(37) Horne, G. P., An Experimental and Computational Investigation into the Radiolysis of PUREX Solvent Systems, Ph.D. Thesis at The University of Manchester, 2015.

(38) http://www.mcpa-software.com/styled-27/ - 20/07/2015.

(39) Ruas, A.; Pochon, P.; Simonin, J.-P. and Moisy, Ph. Nitric acid: modelling osmotic coefficients and acid-base dissociation using the BIMSA theory. Dalton Trans. 2010, 39, $10148-10153$

(40) Hlushak, S.; Simonin, J. P.; De Sio, S.; Bernard, O.; Ruas, A.; Pochon, P.; Jan, S. and Moisy, Ph., Speciation in aqueous solutions of nitric acid, Dalton Trans, 2013, 42, 2853-2860. 
TOC

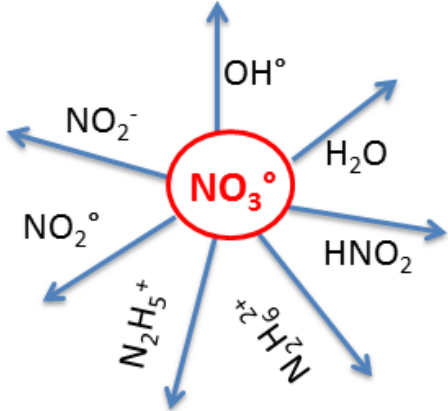

